\title{
Tectonic settings of petroliferous basins in continental China
}

\author{
Institute of Geology, Chinese Academy of Geological Sciences, Beijing 100037, China.
}

The main part of continental China is considered to belong to an interchange tectonic domain between Siberia and Gondwana, where three major global dynamic systems-the Appalachian-palaeo-Asian Ocean, Tethyan-palaeo-Pacific Ocean, and IndianPacific Ocean dynamic systems-were superimposed and compounded, and the resulting polycyclic tectonomagmatism seriously destroyed the petroleum maintenance in marine deposits in most parts of continental China. So, only in polycyclically superimposed basins, Meso-Cenozoic rift basins and piedmont basins of Cenozoic rejuvenated mountain systems can relatively favourable conditions for the generation, accumulation and preservation of petroleum be created. The nonmarine oil origin, polycyclic association of source, reservoir and cap rocks, polycyclically compounded petroleum systems and a variety of oil and gas traps are salient features of the petroliferous basins of China. The Junggar, Turpan-Hami, Tarim, Qaidam, Ordos, Sichuan, Songliao, Bohai Bay, northern Jiangsu-southern Yellow Sea, East China Sea, and South China Sea basins are major regions for hydrocarbon accumulation in China. The tectonism of the Himalayan cycle has special significance for the final shaping of petroleum deposits in most of China's basins.

\section{Introduction}

Since the Qing Dynasty government completed a 1001.4 m-deep artesian well for the production of natural gas in Sichuan in 1840 and a modern drill encountered oil in Miaoli, Taiwan in 1878, China's oil and gas exploration activities have had a history of more than 100 years (Qiu and Gong, 1999), but China's modern petroleum geological surveys only started in the 1920s. The main work before 1950 included: investigation by W.H. Wong and C.Y. Hsieh in the Yumen area of the Hexi Corridor in 1921 (Hsieh, 1922), investigation by T. C. Wang and C.H. Pan in northern Shaanxi in 1932 (Wang and Pan, 1933), investigation by H.C. Tan, C.Y. Lee and C.H. Pan in Sichuan in 1929-1935 (Tan and Lee, 1933; Pan 1936), investigation by C.C. Sun and Shuang Yen in Laojunmiao, Yumen, Gansu (Sun, 1939), investigation by T.K. Huang et al. (1940, 1941, unpublished) in Longchang and Weiyuan, Sichuan in 1942-1943, and investigation by T.K. Huang, C.C. Young and Y.C. Chen in Xinjiang in 1942-1943 (Huang et al., 1947). Since 1950, and especially since 1955, large-scale oil and gas reconnaissance and exploration have been carried out throughout China, but a great majority of their results have not been published formally, with only some compre- hensive works noting them (Zhai, 1987-1996; Lu, 1992; Qiu and Gong, 1999). Systematic theoretical elaboration of China's oil and gas resources began in the 1930s. The main works published in the 1930s and 1940s were: Petroleum (Hsieh, 1930), On problems of petroleum geology in China (Wong, 1934), Petroleum of China accompanied by the Map of distribution of oilfields and oil shales in China (Hsieh, 1935), and Distribution of petroleum resources (Huang, 1942). The period after 1950 witnessed great development of oil and gas exploration in China. The main achievements from 1950 to 1965 included the following: in 1950, W.P. Wong was in charge of compiling the Map of petroleum prospect regionalization of China (Weng et al., unpublished) and T.K. Huang and C.C. Hsieh participated in the compilation; in 1955, J.S. Lee published the paper Prospects for petroleum exploration in China from a tectonic view (Lee, 1955), in which he discussed petroleum resources in China in an all-round way from a tectonic view; in 1956 and 1957, T.K. Huang was in charge of compiling the Map of petroleum prospect regionalization of China (1:3 million) (unpublished), and as chief engineer of the Bureau of Petroleum Geology, former Ministry of Geology, he gave a report titled Preliminary opinions about petroleum prospect regionalization of China at a symposium on petroleum geology (Huang, 1957), in which he explicitly proposed that the Ordos, Sichuan, North China and Songliao plains be taken as the key regions for prospecting; in 1965, Zhu Xia published the paper Tectonic characteristics of Meso-Cenozoic petroleum-bearing basins in China and related problems (Chu, 1965), in which he distinguished three basin types according to the dominant movement systems, i.e., those in the orogenic, epeirogenic and Alpine platform movement systems. After 1978, with the progress of reform and opening to the outside world, there appeared more petroleum geologists and works, e.g., Li Desheng (1982), Tectonic types of oil and gas basins in China; Wang Shangwen et al. (1983), Petroleum geology of China; Zhu Xia (1983), On the geodynamic background of Meso-Cenozoic petroliferous basins of China; Guan Shicong et al. (1984), The changes of land and sea, marine sedimentary facies and hydrocarbons in China; Feng Fukai et al. (1995), Natural gas geology of China; Tian Zaiyi et al. (1996), On petroliferous sedimentary basins of China; Zhang Wenzhao, Major nonmarine oilfields of China; Dai Jinxing et al. (1997), Formation and distribution of medium-large-sized gas fields in China; and Zhang Yuchang et al., Prototypes analysis of petroliferous basins in China. Luo Zhili's paper Geological setting of Chinese petroleum provinces in the book Petroleum exploration in China (eds. Qiu et al., 1999) is the latest work dealing with the tectonics of the petroleum-bearing regions of China from a plate-tectonic point of view.

After more than 50 years of large-scale reconnaissance and exploration, we have acquired the following facts which are a realistic reflection of the geological characteristics of the petroliferous basins in China.

1. Oil and gas in continental China are mainly accumulated within polycyclically superimposed basins that have experienced long-continued stable development, Meso-Cenozoic rift basins, and piedmont basins of Cenozoic rejuvenated mountain systems. The Songliao, Bohai Bay, Sichuan, Ordos, Qaidam, Tarim, Turpan-Hami and Junggar basins are the most important loci of hydrocarbon accumulation in continental China. 
2. The concept that continental or non-marine source beds may give rise to oil fields of economic importance is a salient feature of the theory of oil-gas formation in continental China.

3. Important hydrocarbon formation and accumulation processes occurred in vast areas of China in the Mid-Late Proterozoic, Palaeozoic, Early-Mid Triassic (in South China) and Jurassic (in Tibet) marine deposition stages, but because of the destruction of strong tectono-magmatism, the surviving oil and gas fields of economic value are only located in polycyclically superimposed basins, such as the Sichuan, Ordos, Tarim, North China and northern Jiangsu-southern Yellow Sea basins, which have long been relatively stable and covered with Mesozoic or Meso-Cenozoic deposits.

4. Shelves in China's offshore waters, especially shelf basins in the East China Sea and South China Sea, are the main accumulation areas of offshore oil and gas in China.

5. The multi-type hydrocarbon traps, polycyclic association of source, reservoir and cap rocks and polycyclically compounded petroleum systems are salient features of China's petroliferous basins.

This paper is written on the basis of the Tectonic map of China and adjacent regions (1:5 million) and its brief explanatory notes-The tectonics of China from a global view (Ren et al., 1999), combined with the latest results of petroleum reconnaissance and exploration in China. It is aimed at deciphering the tectonic settings for the formation of the main petroleum-bearing basins in continental China. Owing to the limitation of space, the petroliferous basins in the South China Sea, the East China Sea, and western Taiwan is not dealt with here.

\section{Mid-Late Proterozoic-Jurassic marine petroliferous basins of China-congenitally deficient and suffering from deterioration}

The world's huge petroleum-bearing regions are generally giant marine sedimentary basins, such as the Persian Gulf, Volga-Ural, Alberta, and West Siberia basins. Located mostly on the margins of continents, they have a long history of stable development and have not been subjected to serious destruction since the formation of petroleum accumulations. For example, the Persian Gulf basin had very thick sediments, a good association of source, reservoir and cap rocks, and stable structure from the Cambrian to the Neogene, and only during the closing of the Tethys and the formation of the Zagros orogenic belt and its foreland basin in the Neogene (Beydoun, 1998), did major tectonic movement take place, finally forming the most famous petroliferous region in the world.

Continental China is a composite continent formed by the combination of some small continental blocks (hereinafter referred to as "blocks") and numerous microblocks encompassed in gigantic orogenic belts. Geologically, its northern part belongs to the palaeo-Asian tectonic domain, the southern part to the Tethyan tectonic domain, and the eastern one to the circum-Pacific tectonic domain. The blocks are smaller and less competent than the orogenic belts encompassing them and the magnitude of petroleum generation and accumulation therein is far smaller than that in the aforesaid huge petroleum-bearing regions. The numerous microblocks encompassed within the orogenic belts mostly underwent strong or relatively stronger orogeny, and even if hydrocarbons were generated, all of them dissipated later. Major processes of petroleum generation and accumulation did occur in paraplatform-type small blocks of craton nature, such as the Sino-
Korean, Yangtze and Tarim blocks, in the Mid-Late Proterozoic, Palaeozoic and Triassic, as evidenced by the discovery of a fairly large number of oil shows in areas of marine carbonate rocks in southern and northern China and an old oil deposit in Majiang, Guizhou (Lü, 1992). These oil and gas traps, however, were completely or essentially destroyed by strong tectono-magmatism of the Indosinian and Yanshanian orogenic cycles and could only be partly preserved in the Ordos, Sichuan, Tarim, North China and northern Jiangsu-southern Yellow Sea areas, which are tectonically stable and covered by Mesozoic or Meso-Cenozoic sediments (Figure 1).

In southern China, for example, the processes of generation and accumulation of Sinian-Triassic petroleum were first destroyed by the Indosinian orogeny in the Late Triassic and the earliest Jurassic. Then the Tethys was subducted northwards, the Qinling, SongpanGarzê-Youjiang, and Indo-China-Malay-Sanjiang orogenic belts originated, and the Devonian-Triassic cover in South China suffered
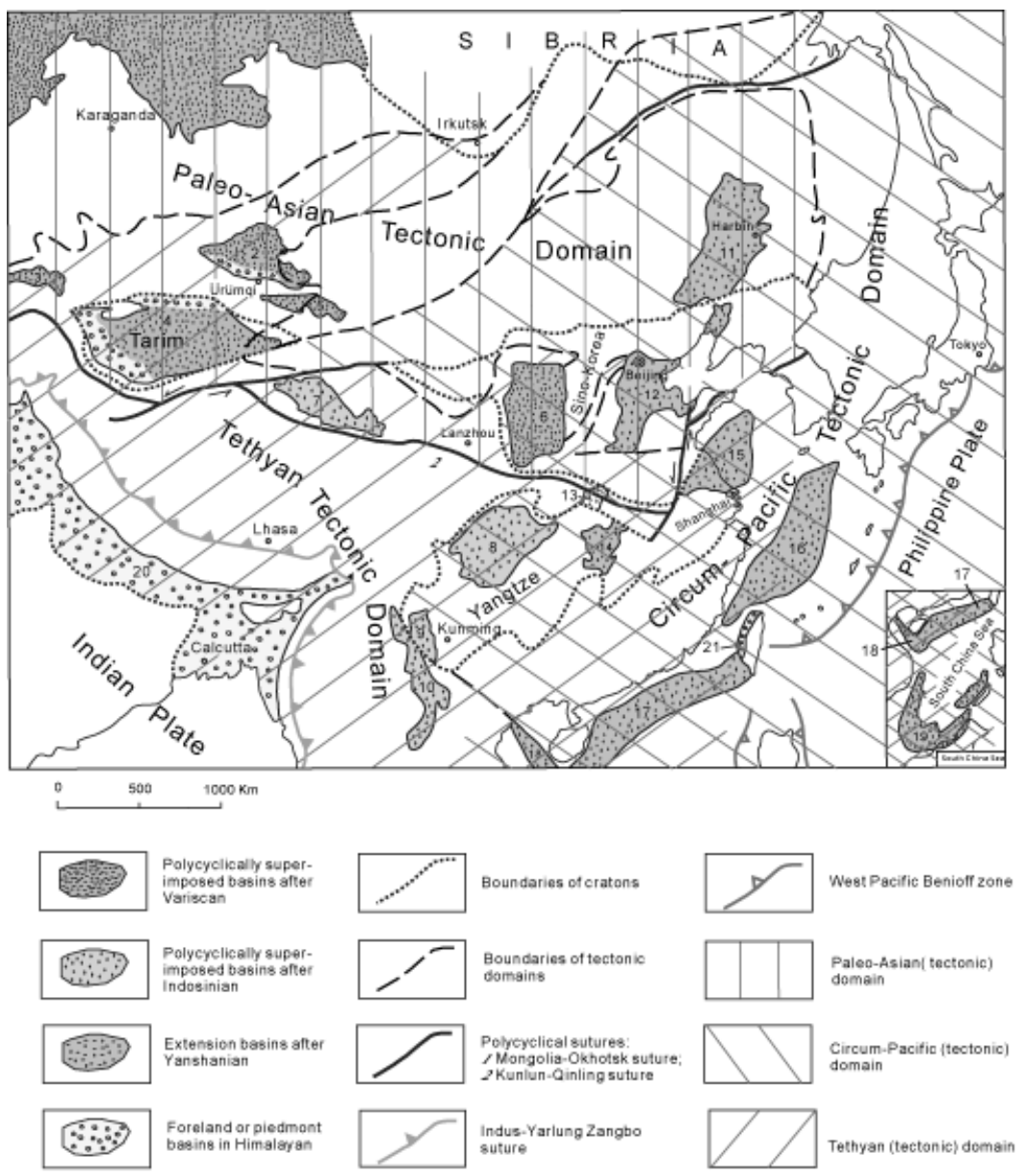

Figure 1 Distribution and tectonic setting of petroliferous basins in East Asia. Basin names: 1. West Siberia basin; 2. Junggar basin; 3. Fergana basin; 4. Tarim basin; 5. Turpan-Hami basin; 6. Ordos basin; 7. Qaidam basin; 8. Sichuan basin; 9. Central Yunnan basin; 10. Lanping-Simao basin; 11. Songliao basin; 12. Bohai Bay basin; 13. Nanyang basin; 14. Jianghan basin; 15. Northern Jiangsusouthern Yellow Sea basin; 16. East China Sea basin; 17. Pearl River mouth basin; 18. Yinggehai basin; 19. Zengmu basin and others; 20. Siwalik foreland basin; 21. West Taiwan foreland basin.

Note: In North and Northeast China, the circum-Pacific domain is super-imposed on the palaeo-Asian domain; in the Tianshan-Baykal belt and Kunlun-QilianNorth Qinling belt, the Tethyan domain is superimposed on the palaeo-Asian domain; in South China the circum-Pacific domain is superimposed on the Tethyan domain, and in the South China Sea area both of them interfere with each other. Polycyclically superimposed basins are the result of the superimposition and compounding of different dynamic systems. 
strong folding, accompanied by intrusion of granitic magma. During the Mid-Late Jurassic, the North American and Asian continents collided along the Anyuy suture zone and the Tethys south of the continent of China was subducted northwards. This combined compression from both the north and south resulted in a strong continental superimposition orogeny between various continents (continental crustal subduction orogeny) and further crustal shortening in East Asia. Strong tectonic deformation and magmatism caused the possible pre-existing oil and gas traps in eastern China (including South China) to experience another great calamity. During the Late Jurassic-earliest Cretaceous, the palaeo-Pacific Ocean disappeared and West Pacifica and the eastern part of the Asian continent collided violently, forming the East Asia marginal Yanshanides and the East China Mesozoic reactivated belt. Then, Proterozoic-Triassic petroleum accumulations in eastern China once again received a crushing blow. During the Cenozoic, the combined action of the collision of India and Eurasia and the formation of the Taiwan orogenic belt as well as the compression, uplift, and strong dissection and erosion of southern China thoroughly destroyed the pre-existing Sinian-Triassic marine oil-gas fields. This is the reason why petroleum exploration in areas of carbonate rocks in southern China fails to find oilgas fields.

In the Qiangtang area of northern Tibet, very thick Triassic-Jurassic marine deposits and the process of petroleum generation have been recognized. However, it seems difficult to find large oil-gas fields there because of the strong influence of the Indosinian, Yanshanian and Himalayan orogenic movements and lack of extensive younger deposits as the cover.

\section{Polycyclically superimposed basins: important oil and gas accumulation loci in China}

\section{Formation of polycyclically superimposed basins in China}

The main parts of the continents other than Asia originated in the pre-Sinian or earliest Cambrian; for example, the North American craton as the main part of the North American continent and the Russian craton as the main part of the European continent both originated in the pre-Sinian; the existing blocks of Gondwana finally were formed in the earliest Cambrian pan-African cycle. On the other hand, the Asian continent where China is located as a whole did originate in the Phanerozoic, though there are also some pre-Sinian blocks. This is the most prominent feature that distinguishes Asia from other continents.

The Asian continent may be defined as Palaeo-Asia, MesoAsia and Neo-Asia according to its development history. PalaeoAsia, belonging to the eastern part of Laurasia and including present-day Central and North Asia, is a region that was assembled dynamically as a whole after the Variscan orogeny before the Late Permian. Meso-Asia, including East and Southeast Asia, went through the Caledonian, Variscan, Indosinian and Yanshanian polycyclic suturing and was assembled in the Mid-Late Jurassic and combined with Palaeo-Asia. Neo-Asia, referring to South Asia, i.e. India, collided with the Eurasian plate in the Cenozoic Himalayan orogenic cycle but was not welded with the latter dynamically at that time (Figure 2).

Corresponding to the formation of Palaeo-, Meso- and NeoAsia and polycyclic orogenies since the Variscan, continental sedimentary basins in China originated separately in the following geological periods.

\section{Late Permian-Middle Triassic sedimentary basins}

Late Permian-Middle Triassic sedimentary basins were the first group of continental sedimentary basins that appeared in China after


Figure 2 Sketch map showing the tectonic evolution of Asia (after Ren, 1999).

the formation of Palaeo-Asia (eastern Laurasia). The formation of the palaeo-Asian continent is not the result of the direct hard collision between the main parts of Gondwana and Siberia and the resulting orogeny, but the result of soft collision and weak orogeny on their complex margins. So after the Variscan orogeny, no obvious uplift took place, nor did real mountains form, but extension occurred once again instead, forming new rift basins. This is the geological setting for the formation of the Late Permian-Middle Triassic basins after the Variscan.

The Late Permian-Middle Triassic continental sedimentary basins mainly include large- and medium-sized basins in Xinjiang and North China and the Beishan-Inner Mongolia-Jilin aulacogen. The North China basin occupies the central part of the Sino-Korean craton, including the vast areas south of the Inner Mongolian axis, north of the North Qinling, west of the Tancheng-Lujiang fault, and east of Alxa (Wang, 1985; Liu, 1986). The basins in Xinjiang embrace the present-day Junggar, Tarim, and Ili basins (Zhou, unpublished). Whether in the Tarim and Junggar basins or in the Ili, Turpan-Hami and Santanghu basins, there are approximately similar Late Permian-Triassic sedimentary sequences and sedimentary characteristics; therefore, it is inferred that these basins would have been connected with each other or connected by channels when mountains, such as the Tianshan Mountains, did not form. The Late Permian-Triassic sedimentary basins in North China and Xinjiang are all of the stable type, lying on the post-Variscan platforms of PalaeoAsia, and their southern margins had a certain relation to the Tethys Ocean. Therefore, in the southern Qilian Mountains there occur Late Permian-Middle Triassic marine deposits, and in the Weibei area of the North China basin there occur Early Triassic marine sedimentary intercalations. The Beishan-Inner Mongolia-Jilin aulacogen is a sedimentary belt sited on the Variscan orogenic belt, occupying the Beishan-Inner Mongolia-Jilin region. Eastwards it was connected 
with the palaeo-Pacific, and after the Indosinian orogeny it was transformed into an orogenic belt.

\section{Late Triassic-Jurassic sedimentary basins}

From the Late Triassic to the earliest Jurassic, the great Indosinian orogeny took place on the Asian continent. This is an orogenic movement generated by subduction of the Tethys-palaeo-Pacific beneath the palaeo-Asian continent, which gave rise to the North Tethys Indosinian orogenic system (including the Kunlun-Qinling, Songpan-Garzê-Youjiang and Karakorum-Sanjiang-Indo-ChinaMalay orogenic belts), the East Asia marginal Indosinian orogenic system (its trace may be found in the present Islands of Japan, i.e., the Akiyoshi tectonic belt), and the Kunlun-Qilian-North Qinling and Beishan-Inner Mongolia-Jilin Indosinian superimposition orogenic belt. The latter orogenic belt resulted from the closing of the aulacogen with the same name.

After the Indosinian cycle, the second group of continental sedimentary basins, i.e., Late Triassic-Jurassic basins, originated in continental China. According to the tectonic relationships, these basins belong to the palaeo-Asian, Tethyan and circum-Pacific tectonic domains, respectively.

Distributed north of the Kunlun-Qinling line, the basins of the palaeo-Asian tectonic domain include large sedimentary basins in Xinjiang and North China, and down-faulted basin swarms developed on the basis of the Indosinian superimposition orogenic belt. The latter may be further divided into two regions: the Qaidam-Qilian region, in which the basin facies is distributed essentially parallel to the old tectonic line, largely striking WNW, and the Beishan-Inner Mongolia-Jilin region, in which the basins strike ENE. The area of the North China basin was somewhat smaller than before, but from an analysis of the sedimentary system and coal potential, the present Ordos, Datong, Ningwu and Yima basins should all belong to the North China basin (Li et al., 1997). The basin area in the Xinjiang region was larger than before, and Tarim, Junggar, Turpan, and Santanghu were also included in the region (Zhou, unpublished).

Lying south of the Kunlun-Qinling line, the basins of the Tethyan tectonic domain consist of the Sichuan-central Yunnan and Qiangtang-Qamdo-Lanping-Simao coal-bearing $\left(\mathrm{T}_{3}-\mathrm{J}_{1}\right)$ and red salt-bearing $\left(\mathrm{J}_{2}-\mathrm{J}_{3}\right)$ basin belts. The former is located in the western part of the Yangtze paraplatform, while the latter is sited on the Sanjiang Indosinides. The marine sediments in the Qiangtang-Simao belt account for a fairly large proportion, because the belt was located immediately adjacent to the Tethys Ocean; especially in its western part-the Qiangtang area, almost all the sediments are marine.

The basins of the circum-Pacific domain, striking NE, are superimposed on the palaeo-Asian and Tethyan tectonic domains. The Late Triassic-Middle Jurassic basin swarm along the coast of southeastern China belongs to this region.

Possibly owing to the influence of climatic zoning, the basins in the palaeo-Asian tectonic domain were in a warm and humid climatic environment in the Early-Mid Jurassic; so the Early-Mid Jurassic was an important coal- and petroleum-forming period in northern China. In the basins of the Tethyan tectonic domain, the Late Triassic witnessed the deposition of coal measures; afterwards the climatic environment was predominantly dry and hot, and as a result these basins became red basins, where significant evaporite sediments were deposited. In the basins along the coast of southeastern China in the circum-Pacific tectonic domain, as they bordered on the palaeo-Pacific Ocean, the climate was humid, and there also occurred coal- and hydrocarbon-forming processes.

Roughly starting at the Middle Jurassic Bajocian Stage, an additional subduction of the Tethys-palaeo-Pacific Ocean beneath the palaeo-Asian continent induced the great early Yanshanian orogenic movement. This movement started in the late Middle Jurassic and reached its culmination in the Late Jurassic, when North America collided with Asia. Synorogenic sediments are represented by those of the Jiulongshan, Tiaojishan, and Tuchengzi formations in the Yanliao area. In this period, the basins, whether in the palaeo-Asian and Tethyan domains or in the circum-Pacific domain, were in a stage of reversion and shrinkage. As the orogeny proceeded, the basins shrank, sediments became coarse-grained, the climate turned from humid to dry, and red sediments occurred. For example, the Toutunhe, Qigu, and Kalaza formations in the Junggar basin, the Zhiluo, Anding, and Fenfanghe formations in the Ordos basin and the Shaximiao, Suining, and Penglaizhen formations in the SichuanYunnan basin are all deposits of this period. At the same time, the development of small basins in orogenic belts basically came to the end, and most of them did not receive sediments. An example of this is the Beishan-Inner Mongolia-Jilin basin swarm that disappeared after the Early-Mid Jurassic (Figure 3).

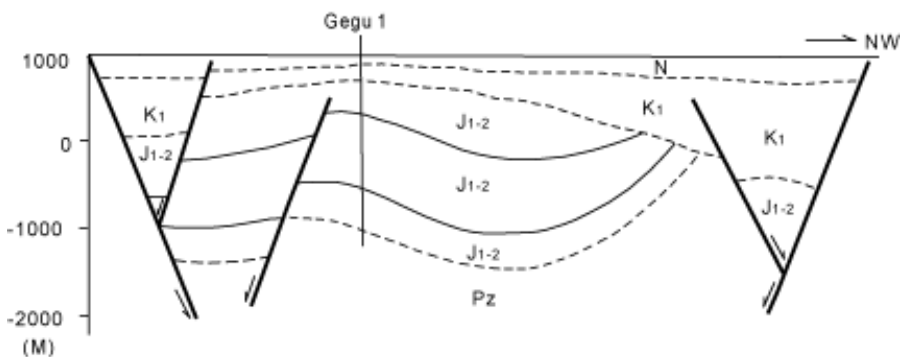

(M)

$\begin{array}{lll}0 & 2 & 4 \mathrm{~km}\end{array}$

Figure 3 Tectonic section of the Gemule'aodu subbasin of the Eren basin (after Zhang Yuchang et al., 1997).

Note: The basin disappeared after the Early-Mid Jurassic $\left(J_{1-2}\right)$ but rose again after the deposition of the Early Cretaceous $\left(K_{1}\right)$ Bayanhua Formation, thus seriously affecting the hydrocarbon potential. Pz, Paleozoic; N, Neogene.

\section{Early Cretaceous sedimentary basins}

The Late Jurassic-early Cretaceous saw the closing of the palaeoPacific Ocean to the east of Palaeo-Asia, and the collision between the palaeo-Asian continent and western Pacifica, as well as the disappearance of the Bangong-Nujiang Ocean to the south of PalaeoAsia, and the collision of the Lhasa massif and the palaeo-Asian continent. As the middle Yanshanian orogeny that occurred after the disappearance of the palaeo-Pacific Ocean resulted from the collision between the two huge continents, it was particularly strong, giving rise to the East Asia marginal Yanshanides and the East China Mesozoic reactivated belt. The latter was an NE-trending huge tectonic belt superimposed on the palaeo-Asian and Tethyan tectonic domains, including the vast region of eastern China east of the Ordos-Sichuan basin. It was this orogeny that finally completed the great transformation of the tectono-dynamic system and the restructuring of the tectonic framework from the start of the Indosinian to the close of the Yanshanian in eastern China. In the Yanshan area, the transformation process finished before the deposition of the volcanic rock series of the Zhangjiakou Formation, while in the coastal area of southeastern China this process ended before the deposition of the volcanic rock series of the Laocun Formation.

After the middle Yanshanian orogeny, the third group of continental sedimentary basins-Early Cretaceous sedimentary basinsoriginated in the continent of China. The famous Jehol fauna was formed in this period. The sedimentary basins in this period may belong to the palaeo-Asian, Tethyan, and circum-Pacific tectonic domains, respectively, according to their tectonic relationships.

In the palaeo-Asian tectonic domain, the large sedimentary basins in Northwest and North China, such as the Tarim, JunggarTurpan, and Ordos basins, continued to develop, but their extent was reduced. The Sichuan-central Yunnan basin and the QiangtangQamdo-Lanping-Simao basin further shrank in the Tethyan tectonic domain. In the circum-Pacific tectonic domain were formed volcanosedimentary basin swarms in the Da Hinggan Mountains and along the coast of southeastern China, and a pull-apart and rift basin swarm represented by the Eren basin in Inner Mongolia. 


\section{Late Cretaceous-Quaternary sedimentary basins}

The most important geological events in China and its adjacent regions in this period were as follows: in the west, the closure of the Tethys Ocean, the collision of India and Eurasia, and the formation of the Himalayan orogenic belt, Qinghai-Tibet Plateau, and Central Asian Cenozoic rejuvenated mountain systems and their related basin systems; in the east, the formation of the Late Cretaceous-Palaeogene rift basin system of eastern China and the Neogene-Quaternary trench-arc-basin system of the western Pacific. China's present tectono-geomorphology characterized by sloping-down from west to east was formed gradually in this period.

After the deposition of the Early Cretaceous Fuxin Formation, eastern China once again underwent shear-compressional orogeny, which was the late Yanshanian orogeny. It was through this orogeny that the process of oblique collisional orogeny between western Pacifica and the palaeo-Asian continent was finally completed, thus putting an end to the stage of the predominant compresso-shear dynamic system in the Mesozoic in eastern China ${ }^{1}$. Afterwards this stage was transformed into the stage of the predominant extensional dynamic system (Ren et al., 1980), and the strike of the sedimentary basins also changed from NE to NNE. This is the Late CretaceousPalaeogene rift basin system in eastern China.

The Late Cretaceous-Palaeogene basins in eastern China are located in different palaeotectonic units. Owing to the differences in foundation and dynamics, these basins have different development histories: The Songliao basin in Northeast China mainly developed in the Late Cretaceous, and shrank in the late Late Cretaceous; the basins in North China were distributed sporadically in the Cretaceous, and large rift basins were formed only in the Palaeogene; basins such as the Jianghan and northern Jiangsu-southern Yellow Sea basins in the Yangtze region were initiated in the Late Cretaceous and developed on a large scale in the Palaeogene; the Hengyang and Nanxiong basins in South China were small in the Cretaceous, and shrank after the Eocene.

In contrast with the transformation from predominant compression to predominant extension in the circum-Pacific tectonic domain in eastern China, the gradual closing of the Tethys and the collision between India and the Asian continent in the Tethyan tectonic domain in western China caused compression to increase progressively, thus inducing the great Himalayan orogenic movement. Therefore, on the basin margins, the mountain masses tended to be thrust over the basins, forming fold and thrust belts and piedmont basins of the Cenozoic rejuvenated mountains, which are similar to the foreland basins in structure.

It is noteworthy that whether on the Qinghai-Tibet Plateau or in the Kunlun, Qilian and Tianshan mountains, Eocene-Miocene sediments are widespread (Cheng, 1990), which suggests that these areas were mostly in a depositional state then, and that in the Palaeogene the western margin of the Tarim basin was still covered by sea water. This may imply that in the early stage of collision between India and Asia the collisional orogeny was not be strong or did not strongly affect these areas, and that strong rejuvenation only took place in the old orogenic belts in western China by the Pliocene-Quaternary, forming the present towering mountains and their related piedmont and intermontane basin systems. This is not only supported by the high degree of consistency in age and depositional sequence between the piedmont Siwalik mollasse deposits of the Himalayas and the piedmont mollasse deposits of the Kunlun, Qilian, and Tianshan mountains
(Huang and Chen, 1981), it is also proved by the latest conclusion that the strongest uplift of the Qinghai-Tibet Plateau took place in the latest Neogene and the earliest Quaternary, as drawn by multidisciplinary research (Sun and Zheng, 1998).

\section{Summary account of the main petroliferous basins in China (Figures 1, 4, 5, 6, 7, 8 and 9)}

\section{Junggar basin}

The Junggar basin is a polycyclically superimposed basin formed after the Variscan orogenic cycle, lying on the pre-Sinian and Caledonian-Variscan double-layer basement ${ }^{2}$. From the Late Permian to the earliest Triassic, a foreland basin occurred for a short time on its southern margin, where the famous oil shale of the Jijicaozi Group and mollasse of the Cangfanggou Group accumulated; afterwards the basin was transformed into a stable craton basin, and went through the Indosinian, Yanshanian and Himalayan polycyclic development process. Oil and gas traps originated in each tectonic cycle and took shape finally in the late Himalayan orogeny during the latest Neogene to the earliest Quaternary. This point is more important for the piedmont basin of the Tianshan Mountains on the southern margin of the basin, whereas the petroleum accumulations in the northern part of the basin may have essentially taken shape before the Cretaceous.

\section{Turpan-Hami basin}

The Turpan-Hami and Junggar basins are generally considered one basin or two parts of one basin. During the Triassic to Jurassic they shared roughly the same history of development and were not separated into two basins until the Cretaceous.

\section{Tarim basin}

The Tarim basin is also a polycyclically superimposed basin formed after the Variscan orogenic cycle, in which two important piedmont basins-Kuqa and Kashi-Hotan-are developed. The difference lies in the fact that the continental deposits of the Tarim basin are superimposed on the Palaeozoic, predominantly marine sedimentary cover, and that the Palaeozoic strata are divided into several sedimentary sequences and hydrocarbon systems with the S/O, C/D, and $\mathrm{P}_{2} / \mathrm{P}_{1}$ unconformities as boundaries. Thus, the Tarim basin is actually a polycyclically superimposed basin that developed after the Yangtzean (Jinningian) orogenic cycle. Among the orogenic cycles, the Caledonian and Variscan cycles form a marine platform cover stage, and the Indosinian, Yanshanian and Himalayan cycles form a continental basin stage. The polycyclic generation and accumulation of petroleum resulted in the formation of a polycyclic petroleum sys-

\footnotetext{
${ }^{1}$ Some people think that the strong Mesozoic tectonic movement in eastern China is the result of subduction of the so-called Kula plate beneath the Asian continent, but actually this is only a conjecture proposed according to some submarine magnetic stripes. We incline to the inference that the western Pacific had been an old land, as proposed according to geological, geophysical and submarine drilling data. This inference has been mentioned in our previous works (Ren et al., 1990, 1999) and will not be detailed here.

2 The basement of the Junggar basin has long been disputed. According to Peng Xiling's paper and the results of aeromagnetic surveys and geological mapping (the Zhifang Sheet), we believe in the view that the pre-Sinian basement is hidden there.
} 
tem. The hydrocarbon traps finally took shape also in the latest phase of the Himalayan cycle, i.e., in the latest Neogene to earliest Quaternary (Figure 5). so the two basins are the most stable areas in the Yangtze and SinoKorean paraplatforms.

The Ordos basin is a remnant of the Late Permian-Jurassic North China basin with a marine sedimentary cover of the MidUpper Proterozoic and Cambrian-Ordovician
deposits and the Carboniferous-Permian coal measures being below the Upper Permian. It is a polycyclically superimposed basin formed since the Proterozoic. Its formation progressed through the process of the Yangtzean, Caledonian, Variscan, Indosinian, Yanshanian and Himalayan polycyclic evolution, during which a polycyclic petroleum system originated. Except on the basin margins, the sedimentary strata generally maintain a subhorizontal state. On the western margin the important Caledonian, Indosinian, Yanshanian and Himalayan orogenies occurred, generating folds, overthrusts and strike-slip faults; on the northern, southern and northwestern margins Cenozoic grabens, such as the Fenwei, Hetao, and Yinchuan grabens, encircle the basin. The petroleum accumulations took final shape in the Himalayan cycle (Figure 6).

\section{Qaidam basin}

The Qaidam basin, located on the Indosinian and, still older basement, is a basin formed by superimposition of the Himalayan cycle basin on the Yanshanian one. The thickness of the Paleogene and Neogene deposits may reach a maximum of over $10 \mathrm{~km}$. The petroleum traps also took final shape in the late phase of the Himalayan cycle, i.e. in the latest Neogene to the earliest Quaternary.

For many years, some researchers have thought that the Qaidam and Tarim basins were connected with each other and had the same pre-Sinian basement, but the available data do not support this view. Although the pre-Sinian metamorphic series is widely exposed in the Altun Mountains, it is a metamorphic series at the root of an oro-



Figure 6 Tectonic section across the Ordos basin (after Zhang Yuchang et al., 1997).

Note: Thrusts occur on the western side of the basin; eastwards, the Cambrian-Ordovician $(€+O)$, Carboniferous Permian $(C+P)$, Triassic $(T)$, and Jurassic $(J)$ show no change in thickness, suggesting that the Ordos basin is actually a remnant of the North China basin. genic belt that was strongly reworked by the Caledonian, Variscan and even Indosinian orogenies (Zhang et al., 1999,2001 ), which is utterly different from the pre-Sinian metamorphic series that acts as the basement of the Tarim basin. The discovery of Palaeozoic ophiolites and ultrahigh-pressure metamorphic rocks (Yang and Deng, 1994; Yang et al., 1998) proves that the Altun Mountains are really a Palaeozoic orogenic belt, being a part of the Kunlun-Qilian-Qinling orogenic system. The boundary between this orogenic belt and the Tarim craton (paraplatform) stretches along the Qarqan River fault zone (Ren et al., 1980; Ren et al, 1999). Therefore, it was impossible for the pre-Sinian basement of the Tarim basin to extend down through the Altun Mountains below the Qaidam basin.

Pre-Sinian strata are also exposed in zonal form in the northern and southern parts of the Qaidam basin, but the recognition of the Qimantag and northern Qaidam marginal Caledonides proves that these pre-Sinian zones are geological units in orogenic belts too. Therefore, we say that in Qaidam there is a collage basement formed in the Indosinian orogenic cycle, and the basement consists dominantly of pre-Sinian to Early Palaeozoic rocks, which have undergone strong reworking of the Variscan and Indosinian orogenies. So the Qaidam basin is a polycyclically superimposed basin formed after the Indosinian cycle.

\section{Ordos and Sichuan basins}

Viewing the geological and tectonic maps of China as a whole, only the sedimentary covers of the Sichuan and Ordos basins are free from the strong influence of the Phanerozoic orogenic movements;

The Sichuan basin is a remnant of the Late Triassic-Cretaceous Sichuan-central Yunnan basin with a Sinian-Middle Triassic marine sedimentary cover lying below the Late Triassic-Cretaceous continental sediments. This is a polycyclically superimposed basin formed after the Yangtzean orogenic cycle. The front of the Late Triassic Longmen Mountains and the front of the Middle Jurassic Daba Mountains had some features of the foreland basin. On the eastern side of the basin an NE-directed fold system was formed in the late Yanshanian-Himalayan period, whereas on the eastern margin of the Longmen Mountains, some of the sediments of the basin is buried by the mountains because of overthrusting and superimposition in the Indosinian, Yanshanian and Himalayan orogenic cycles, and the southern margin of the Daba Mountains is also marked by an overthrusting-superimposition system formed mainly in the Indosinian and Yanshanian orogenic cycles. So, generally speaking, there is also a polycyclic hydrocarbon system in the Sichuan basin, and the oil and gas traps took final shape during the Himalayan cycle (Figure 7).

\section{Songliao basin}

The Songliao basin is a rift-depression basin formed after the Yanshanian cycle. It is mainly made up of Cretaceous formations, with a relatively simple history of development. It is located on the Beishan-Inner Mongolia-Jilin Caledonian-Variscan-Indosinian polycyclic orogenic belt (Figure 8). As the eastern segment of this orogenic belt was formed on the basis of the fragmentation of the Jihei mosaic massif, we believe that a Xingkaian metamorphic basement is hidden beneath the Songliao basin. 


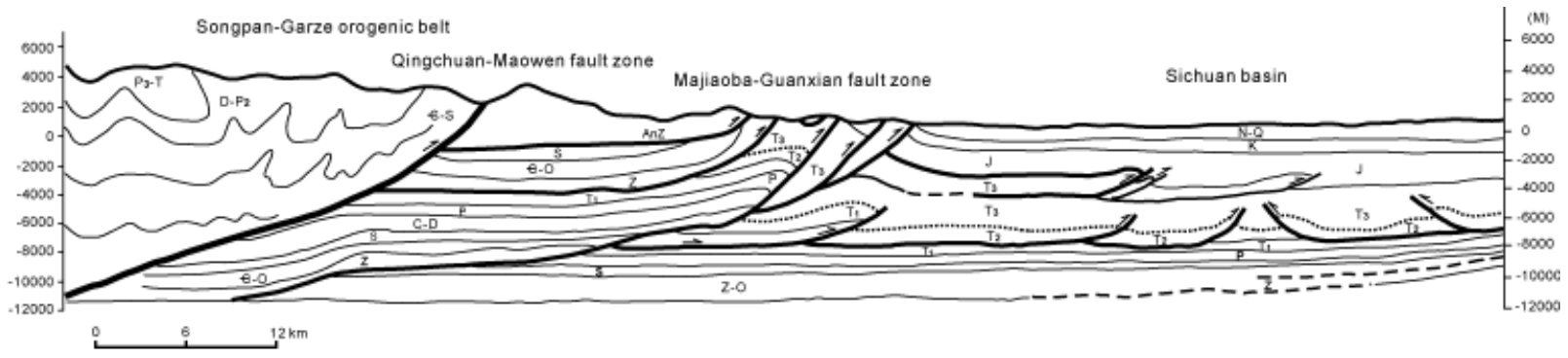

Figure 7 Tectonic section on the western margin of the Sichuan basin (according to the geological-geophysical interpretation profile of the central segment of the Longmen Mountains, modified from Zhang Yuchang et al., 1997).

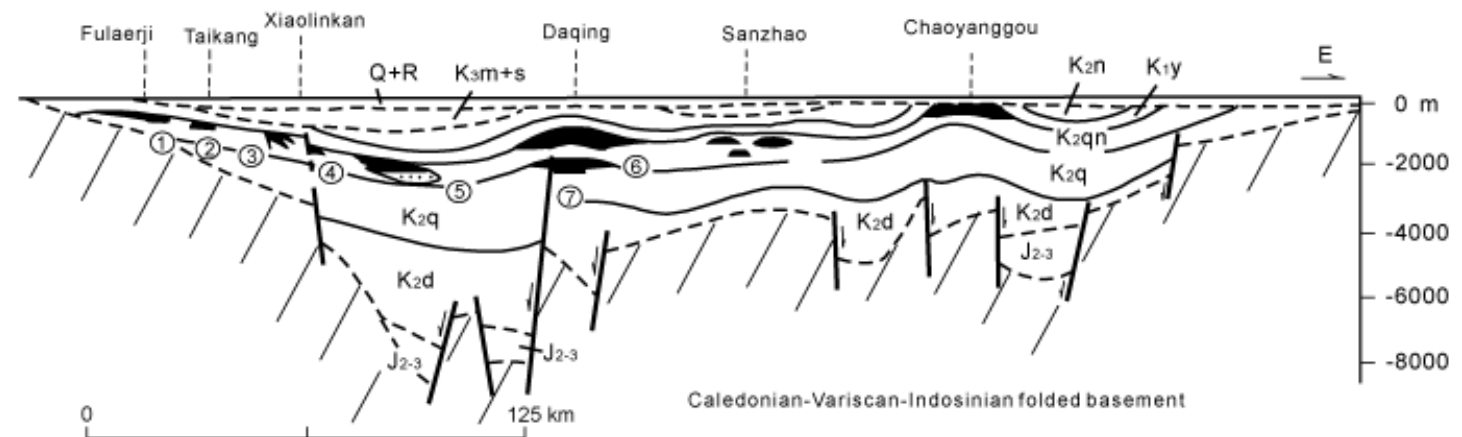

Figure 8 Tectonic section of the Songliao basin (modified from Tian Zaiyi et al., 1996).

$K_{I}$-Lower Cretaceous; $K_{2} d$-Denglouku Formation; $K_{2} q-Q u a n t o u$ Formation; $K_{2} q n-Q i n g s h a n k o u$ Formation; K2y-Yaojia

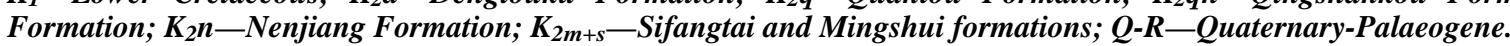

(1) Stratigraphic overlap trap; (2) Minor anticlinal trap; (3) Rollover anticlinal trap; (4) Fault-screened trap; (5) Sandstone concave-lens trap; (6) Anticlinal trap; (7) Faulted-anticlinal trap.

\section{Bohai Bay basin}

The Bohai Bay basin is a large Paleogene-Neogene rift basin as well as the largest rift basin in continental China, the formation of which would be associated with the upwelling of mantle plume in the Bohai Sea $(\mathrm{Li}, 1980)$. It is sited on the folded cover of the Sino-Korean paraplatform, and below it might be hidden a Triassic-Jurassic or Cretaceous remnant basin. The Mesoproterozoic-Palaeozoic sedimentary cover of the Sino-Korean paraplatform also has a history of petroleum generation and accumulation; so there should be Proterozoic-Mesozoic residual reservoir traps and Cenozoic newborn old traps (buried-hill traps). Meanwhile it must also be pointed out that in the continental part of the Bohai Bay basin the hydrocarbon generation and accumulation mainly occurred in the Palaeogene system, while the Neogene has little significance. In the sea area of the basin, however, the Neogene system is very thick and there might be marine intercalations. Therefore, both the Palaeogene and Neogene should be the important targets of petroleum exploration (Figure 9).

\section{Northern Jiangsu-southern Yellow Sea basin}

The northern Jiangsu-southern Yellow Sea basin is a polycyclically superimposed basin, which was formed after the Indosinian cycle but mainly developed in the Late Cretaceous to Neogene. It is noteworthy that below Mesozoic continental deposits in the basin lies the Sinian-Triassic marine sedimentary cover, whose hydrocarbon potential is still a puzzle. This basin is a tectonically stable area in the eastern part of the Yangtze paraplatform and Mesozoic tectonic movement here was much weaker than that in the Mount Ningzhen, southern Jiangsu and the Sujiao area of northern Jiangsu; therefore, further work is necessary.

Above, we have briefly discussed the major petroliferous basins in China. They are mostly polycyclically superimposed basins that have experienced long-continued stable development and MesoCenozoic rift basins. Below these basins are mostly pre-Sinian or Precambrian basements, so they have great tectonic stability. The Tarim, Sichuan, Ordos and northern Jiangsu-southern Yellow Sea basins are located on the pre-Sinian cratons and the Junggar, TurpanHami and Songliao basins rest on the Variscan or Variscan-Indosinian basement. But geophysical data indicate that below them there might be still older Proterozoic basements (Airborne Geophysical and Remote Sensing Center, Ministry of Land and Resources, unpublished). Although there is no relatively complete old basement below the Qaidam basin, there are blocks and patches of metamorphic rocks reworked by late-stage orogeny. That is to say, the long-

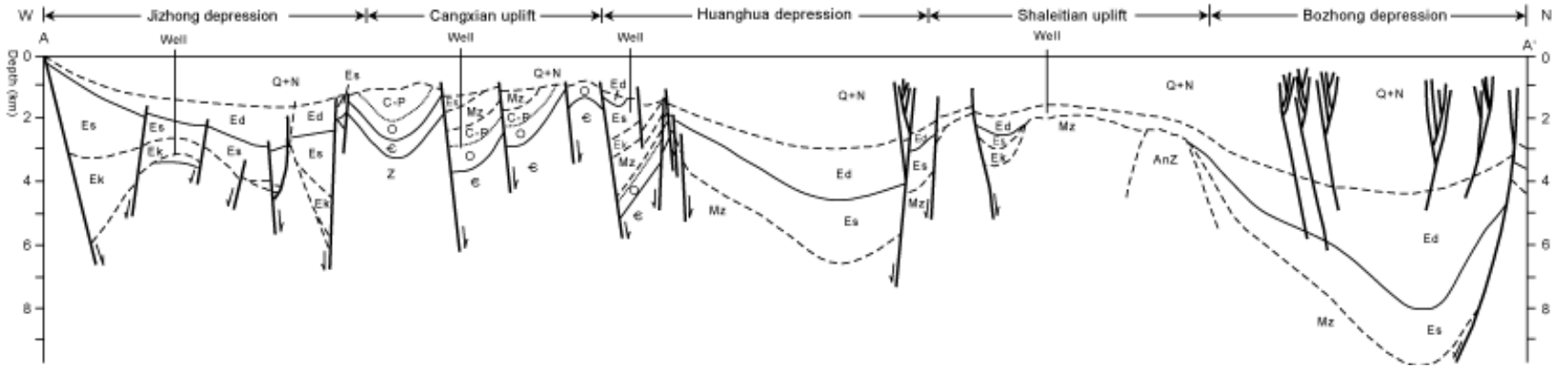

Figure 9 Simplified geological section of the Bohai Bay basin (after Gong Zaisheng, 2001).

Note: The Neogene $(N)$ and Quaternary $(Q)$ sediments in the Bozhong subbasin thicken abruptly. Mz, Mesozoic. 
continued development and relatively stable tectonic environment of these basins are prerequisites for the formation of large oil-gas fields.

\section{China's petroliferous basins from a global geodynamic view}

The petroleum resources of the world are mainly distributed in the following regions: passive continental margins on the opposite coasts of the Atlantic Ocean, active continental margins on the opposite coasts of the Pacific Ocean, foreland basin zones in the Tethyan orogenic belt, and large sedimentary basins in the North American and Eurasian continents.

Generally speaking, one megastructural oil and gas field is mainly controlled by one dynamic system. For example, the Persian Gulf petroliferous basin is mainly controlled by the Tethyan dynamic system; and the North Sea petroliferous basin of Europe and the Gulf of Mexico petroliferous basin of North America, by the Atlantic dynamic system; and the Cordillera foreland basin petroleum accumulation zone of North and South America, by the Pacific dynamic system. But this is not the case with the petroleum-bearing areas in the continent of China. As the Chinese continent was situated in the interchange tectonic domain between Siberia (and later Laurasia) and Gondwana, it was controlled successively by the Appalachian-palaeo-Asian Ocean, Tethys-palaeo-Pacific Ocean, and Indian Ocean-Pacific Ocean dynamic systems in the geological past, forming the palaeo-Asian, Tethyan and circum-Pacific tectonic domains. The superimposition and compounding of the three dynamic systems caused China to become the region with the most complex tectonics in the world. Owing to the polycyclic orogenic movements and ensuing occurrence of polycyclically compounded orogenic belts and polycyclically superimposed basins, most petroliferous basins in China are characterized by multiple types of oil and gas traps, polycyclic association of source, reservoir and cap rocks, and polycyclically compounded hydrocarbon systems.

In the Palaeozoic stage, China was mainly controlled by the Appalachian-palaeo-Asian Ocean dynamic system, and the Xingkaian (Salairian), Caledonian and Variscan polycyclic orogenies brought about folding and metamorphism of most of the Palaeozoic deposits. Therefore, it was only after the complex marginal collision between Siberia and East Gondwana and the formation of the palaeo-Asian continent in the Late Permian that China's first group of sedimentary basins could generate, accumulate and preserve petroleum initiated in the East Asian continent.

In the Meso-Cenozoic stage, the continent of China was successively controlled by the Tethys-palaeo-Pacific Ocean and Indian Ocean-Pacific Ocean dynamic systems. The superimposition of the two dynamic systems on the palea-Asian continent and the mutual interference of the two dynamic systems caused China's Meso-Cenozoic basins to have a complex and highly varied evolutionary history. Relatively favourable conditions for petroleum generation, accumulation, and preservation could be created only in polycyclically superimposed basins that had experienced long-continued stable development, i.e., basins formed by the superimposition of sedimentary basins of different tectonic cycles and types, and large Cenozoic rift basin, as well as piedmont or foreland basins. This is the basic reason why the oil and gas resources of China are mainly distributed in the Junggar, Turpan-Hami, Tarim, Qaidam, Ordos, Sichuan, Songliao, Bohai Bay, northern Jiangsu-southern Yellow Sea, East China Sea and South China Sea basins.

The superimposition and compounding of the three major dynamic systems and their resulting polycyclic tectono-magmatism brought about serious destruction of the petroleum preservation conditions in marine sedimentary basins in most parts of the continent of China. Therefore, marine oil and gas traps can be preserved and conditions for hydrocarbon generation in marine deposits can be created once again only in areas, such as Sichuan, Ordos, Tarim, North
China, and northern Jiangsu-southern Yellow Sea, which are relatively stable and covered by Meso-Cenozoic deposits.

Petroleum is a fluid mineral and its generation, migration and accumulation must abide by the conditions of fluid dynamics. As China's present geology, tectonics, geomorphology, and fluid dynamic conditions were finally formed in the late Himalayan cycle, i.e., the Neogene to earliest Quaternary, most reservoirs, traps and seals in various sedimentary basins were also finally shaped in this period. That is to say, Cenozoic tectonic movement has special significance for the formation of petroleum accumulations in most basins of China. This is particularly the case with gas accumulations in China (Feng et al., 1995).

\section{Acknowledgments}

After the primary manuscript was finished, it was presented at the Symposium on the New Progress in the Study of Petroliferous Basins (sponsored by the Chinese Petroleum Society, held in Jiujiang, May 2000) and the Symposium on the Application of Zhu Xia's Petroleum Exploration Geological Theory (sponsored by the Wuxi Institute of Experimental Geology, China National Petrochemical Corp., held in Wuxi, November 2000), and also reported at the Symposium on the Exploration Potential of the Shengli Oilfield (Qingdao, May 2001). Opinions and comments were solicited at these symposiums. During the preparation of this paper, Peng Xiling, Gong Zaisheng and other geologists provided us with valuable data and maps, and Xu Wang, Zhang Qing, Zhao Zhengzhang and other petroleum specialists sent us the latest works on petroleum geology. After completion of the manuscript, Li Desheng, an academician of the Chinese Academy of Sciences reviewed the whole manuscript and provided related information. The English translation was done by Fei Zhenbi. Here we would like to express our heartfelt thanks to all of them.

\section{References}

Beydoum, Z. R., 1998, Arabian plate oil and gas: Why so rich and so prolific?: Episodes, v. 21, no. 2, pp. 74-81.

Cheng Yuqi, chief ed., 1990, Geological Map of China (1:5000 000): Geological Publishing House, Beijing (in Chinese).

Dai Jinxing, Wang Tingbin, Song Yan, Zhang Hongnian, Xu Yongchang, Zhang Qiming et al., 1997, Formation and distribution of medium-largesized gas fields in China: Geological Publishing House, Beijing, 300p (in Chinese with English Preface).

Ding Daogui, Tang Liangjie, Qian Yixiong et al., Formation and evolution of the Tarim basin: Hehai University Press House, Nanjing, 302 p. (in Chinese with English abstract).

Feng Fukai, Wang Tingbin, Zhang Shiya, Zhang Hongnian, Liu Guobi, You Xiuling, and Gao Jianjun, 1995, Natural gas geology in China: Geological Publishing House, Beijing, 355 p (in Chinese).

Gan Kewen, chief ed., 1992, Sedimentary basin and petroleum distribution map of the world (1:15 000 000): Petroleum Industry Press, Beijing.

Guan Shicong, chief ed., 1984, The changes of land and sea, marine sedimentary facies and hydrocarbons in China: Science Press, Beijing, $104 \mathrm{p}$ (in Chinese).

Hsieh, C. Y., 1922, Report on oil in Yumen, Gansu: Hunan Industry Journal, no. 54 (in Chinese).

Hsieh, C. Y., 1930, Petroleum: Commercial Press, Beijing, 135 p. (in Chinese).

Hsieh, C. Y., 1935, Petroleum of China: Acta Geographica Sinica, v. 1, no. 2 (in Chinese).

Huang, T. K., 1942, Distribution of petroleum resources, in Selected works of Huang Jiqing on petroleum geology, 1993: Science Press, Beijing, pp. $1-5$ (in Chinese).

Huang, T. K., Young, C. C., Cheng, Y. C., Bien, M. N., Chow, T. C., and Wong, W. P., 1947, Report on geological investigation of some oil-fields in Sinkiang: Geol. Memoirs, Ser. A, no. 21, pp. 1-118, 14 colored pls.

Huang Jiqing (Huang, T. K.), 1957, Preliminary opinions about petroleum prospect regionalization of China, in Selected works of Huang Jiqing on petroleum geology, 1993: Science Press, Beijing, pp. 112-125 (in Chinese). 
Huang Jiqing (Huang, T. K.), and Chen Bingwei, 1980, On the formation of Pliocene-Quaternary molasses in the Tethys-Himalayan tectonic domain and its relation with the Indian plate motion, in Scientific papers on geology for international exchange-prepared for the $26^{\text {th }}$ International Geological Congress, 1, Tectonic geology and geological mechanics: Geological Publishing House, Beijing, pp.1-14 (in Chinese with English abstract).

Khain, V. E., chief ed., 1981, Tectonic map of the world (1:15 000000$)$ : Subcommission for the Tectonic Map of the World, CGMW.

Li Desheng, 1980, Geological structure and hydrocarbon occurrence of Bohai Gulf oil and gas basin, in CNPC ed., Selected works of the academicians of the Chinese Academy of Sciences-Li Desheng: Encyclopedia of China Publishing House, Beijing, 1997, pp. 32-56 (in Chinese with English abstract).

Li Desheng, 1982, Tectonic types of oil and gas basins in China: Acta Petrolei Sinica, v. 3, no.3, pp. 1-12 (in Chinese with English abstract).

Lee, J. S., 1955, Prospects for petroleum exploration in China from a tectonic view: Acta Petrolei Sinica, no. 16, pp. 1-40 (in Chinese).

Li Sitian, Lu Fengxiang, Lin Changsong et al., 1997, Evolution of Mesozoic and Cenozoic basins in eastern China and their geodynamic background: China University of Geosciences Press, Wuhan, pp. 1-239 (in Chinese with English abstract).

Liu Shaolong, 1986, The existence of a large-scale Triassic sedimentary basin in North China: Acta Geologica Sinica, v. 60, no. 2, pp. 128-138 (in Chinese with English abstract).

Luo Zhili, 1999, Geological setting of Chinese petroleum provinces, in Qiu Zhongjian and Gong Zaisheng, eds., Petroleum exploration in China: Petroleum Industry Press, Geological Publishing House, Beijing, pp.1-19 (in Chinese with English foreword).

Lü Hua , chief ed., 1992, Prospecting and discovery of oil and gas in China: Geological Publishing House, Beijing, 427 p. (in Chinese).

Pan, C. H., 1936, Brief report on the oilfields in Szechuan Province: Acta Geologica Sinica, v. 1, no. 6, pp. 633-650 (in Chinese with English abstract).

Pan, C. H., 1941, Non-marine origin of petroleum in north Shensi, and the Cretaceous of Szechuan, China: Bulletin of the American Association of Petroleum Geologists, pp. 2058-2067.

Qiu Zhongjian, and Gong Zaisheng, chief eds., 1999, Petroleum exploration in China: The Petroleum Industry Press, Geological Publishing House, Beijing, pp.1-194 (in Chinese with English foreword).

Ren Jishun, Chen T ingyu, Niu Baogui, Liu Zhigang and Liu fengren, 1990, Tectonic Evolution of the continental Lithosphere and metallogeny in Eastern China and adjacent areas. Science Press, Beijing, 205p (in Chinese).

Ren Jishun, Jiang Chunfa, Zhang Zhengkun, and Qin Deyu, 1980, Geotectonic evolution of China: Science Press, Beijing, 124 p. (in Chinese; English version, 1987: Science Press, Springer-Verlag, 203pp.).

Ren Jishun, chief ed., 1999, Tectonic map of China and adjacent regions (1:5000000): Geological Publishing House, Beijing.

Ren Jishun, chief ed., 1999, The tectonics of China from a global view-A guide to the tectonic map of China and adjacent regions: Geological Publishing House, Beijing, 32p.

Sun Honglie, and Zheng Du, chief eds., 1998, Formation, evolution and development of Qinghai-Xizang (Tibetan) Plateau: Guangdong Science \& Technology Press, Guangzhou, pp. 1-350 (in Chinese with English introduction).

Sun, C. C., 1939, Report on geology in Yumen oilfields, Gansu, in Selected geological works of Sun Jianchu, 1998: Petroleum Industry Press, Beijing, pp. 234-259 (in Chinese).

T'an, H. C., and Lee, C. Y., 1933, Oil fields in Szechuan Province: Bull. Geol. Surv. China, no. 22, pp. 1-38.

Tian Zaiyi, and Zhang Qingchun, 1996, On petroliferous sedimentary basins of China: Petroleum Industry Press, Beijing, 311 p (in Chinese).

Wang Hongzhen, chief ed., 1985, Atlas of the palaeogeography of China: Cartographic Publishing House, Beijing.

Wang Shangwen et al. eds, 1983, Petroleum geology of China: Petroleum Industry Press, Beijing, 348 p (in Chinese).

Wong, W. H., 1934, On problems of petroleum geology in China: Nature Weekly, no. 60 (in Chinese).

Wang Zhuquan, and Pan Zhongxiang, 1933, Geology of the oil fields in northern Shensi: Bull. Geol. Surv. China, no. 20.

Yang Jianjun, and Deng Jinfu, 1994, Garnet peridotites and eclogites in the north Qaidam mountains, Tibetan plateau: a first record, in First Workshop on UHP Metamorphism and Tectonics, December 1-3, 1994, organized by International Lithosphere Program Task Group III-6, Stanford University.
Yang Jingsui, Xu Zhiqin, Li Haibing, Wu Cailai, Cui Junwen, Zhang Jianxin, and Chen Wen, 1998, Discovery of eclogite at northern margin of Qaidam baisin, NW China: Chinese Science Bulletin, v. 43, no. 20, pp. 1755-1759.

Zhai Guangming, chief ed., 1996, Petroleum geology of China, v. 1, Introduction: Petroleum Industry Press, Beijing, pp. 1-615 (in Chinese with English preface)

Zhang Jianxin, Xu Zhiqin, Yang Jingsui, Zhang Zeming, and Cui Junwen, 2001, Petrology, geochemistry and geochronology of eclogites from the western segment of the Altun tectonic belt, northwestern China: Acta Geologica Sinica, v. 75, no. 2, pp. 186-197 (in Chinese with English abstract).

Zhang Jianxin, Zhang Zeming, Xu Zhiqin, Yang Jingsui, and Cui Junwen, 2000, The ages of U-Pb and Sm-Nd for eclogite from the western segment of Altyn Tagh tectonic belt: Chinese Science Bulletin, v. 44, no. 24, pp.2256-2259.

Zhang Wenzhao, chief ed., 1997, Major nonmarine oilfields of China: The Petroleum Industry Press, Beijing, pp. 1-1038 (in Chinese with English introduction).

Zhang Yuchang et al., 1997, Prototype analysis of petroliferous basins in China: Nanjing University Press, Nanjing, pp. 1-434 (in Chinese with English abstract).

Zhu Xia (Hsia Chu), 1965, Tectonic characteristics of Meso-Cenozoic petroleum-bearing basins in China and related problems, in Problems of tectonics in China: Science Press, Beijing.

Zhu Xia (Hsia Chu), 1983, On the geodynamic background of Meso-Cenozoic petroliferous basins of China, in Zhu Xia, ed., Tectonics and evolution in Mesozoic and Cenozoic basins of China: Science Press, Beijing, pp. 1-10 (in Chinese).

Ren Jishun Academician of the Chinese Academy of Sciences, Chairman of the Commission on Tectonics, Geological Society of China, Secretary General of the CGMW Continental Subcommission for South \& East Asia. Since the middle of the 1950s, he has devoted his energy to the research of China's tectonics. He published the books "Geotectonic Evolution of China" in 1980 and "Tectonic Evolution of the Continental Lithosphere and Metallogeny in Eastern China and Adjacent Areas" in 1990, and as chief editor, compiled in 1999 the "Tectonic Map of China and Adjacent Regions (1:5000 000)" with its guide "The Tectonics of China from a Global View".

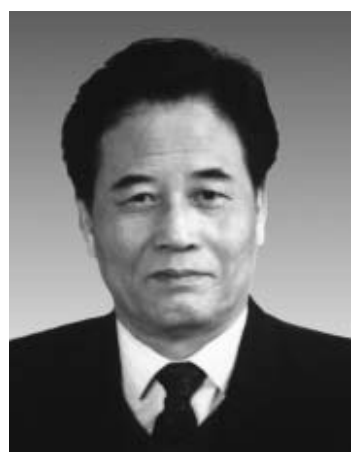

Xiao Liwei graduated from the China University of Geosciences in 1982. She is currently senior engineer at the Institute of Geology, Chinese Academy of Geological Sciences, and is assistant to Acad. Ren Jishun.

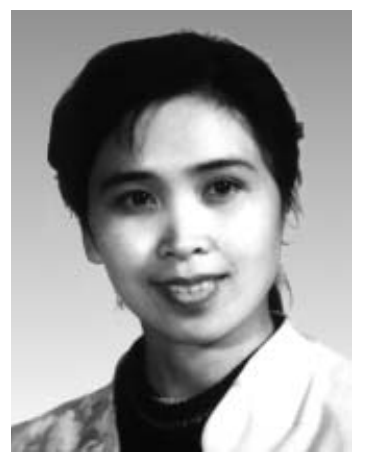

